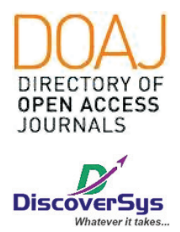

Published by DiscoverSys

\section{Faktor-faktor resiko kejadian pneumonia pada pasien pneumonia usia 12-59 bulan di RSUD Wangaya}

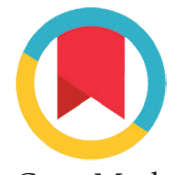

CrossMark

\author{
Susan Natalia Budihardjo," I Wayan Bikin Suryawan
}

\section{ABSTRACT}

Background: Pneumonia is the leading cause of under five children's mortality worldwide. In Indonesia, pneumonia still the second largest cause of mortality in infants (12.3\%) and under five children (13.2\%) after diarrhea. However, the incidence of pneumonia didn't receive some attention so it's often referred as "the forgotten killer of children". Therefore, the aim of our study is to control pneumonia in children under five by investigating the risk factors of pneumonia.

Methods: A case control study was conducted from January 2019 to May 2019 by using the consecutive sampling methods. The subjects were children aged 12-59 months old with pneumonia at Wangaya Hospital for the case and children aged 12-59 months old without pneumonia at Wangaya Hospital for the control. Subject's characteristics such as gender, age, weight birth, immunization status, exclusive breastfeeding status, history of asthma, smoke exposure, and nutritional status. Matching was performed on exclusive breastfeeding variable. Will be done the bivariate analysis with McNemar and multivariate analysis with logistic regression.

Result: Among 96 subjects divided into 48 subjects in each group. Bivariate analysis showed that immunization status ( $p$-value 0.009 , OR 5.209) and smoke exposure ( $p$-value 0.008, OR 2.238) were the significant risk factors of pneumonia. While gender, nutritional status, and history of asthma weren't significant risk factors of pneumonia in children under five at Wangaya Hospital.

Conclusion: Incomplete immunization status and exposed to cigarette smoke are the risk factors of pneumonia in children aged 12-59 months old at Wangaya Hospital.
Bagian/SMF IImu Kesehatan Anak RSUD Wangaya, Bali-Indonesia

\section{*Korespondensi:}

Susan Natalia Budihardjo; Bagian/ SMF IImu Kesehatan Anak RSUD

Wangaya, Bali-Indonesia

susan_natalia_ljc@ymail.com

Diterima: $16-10-2019$

Disetujui: 03-02-2020

Diterbitkan: 01-04-2020

Keywords: pneumonia, children under five, risk factors

Cite This Article: Budihardjo, S.N., Suryawan, I.W.B. 2020. Faktor-faktor resiko kejadian pneumonia pada pasien pneumonia usia 12-59 bulan di RSUD Wangaya. Intisari Sains Medis 11(1): 398-404. D0I: 10.15562/ism.v11i1.645

\title{
ABSTRAK
}

Latar Belakang: Pneumonia merupakan pembunuh nomor satu balita di dunia. Di Indonesia, Pneumonia menduduki peringkat kedua penyebab kematian bayi $(12,3 \%)$ dan balita $(13,2 \%)$ setelah diare. Sayangnya, kejadian pneumonia tidak begitu banyak mendapat perhatian khusus. Tujuan penulisan laporan kasus ini adalah mempelajari faktor-faktor resiko yang menyebabkan pneumonia.

Metode: Dengan menggunakan studi kasus-kontrol yang dilakukan pada bulan Januari 2019-Mei 2019 menggunakan metode sampel konsekutif. Subjek penelitian adalah anak berusia 12-59 bulan dengan pneumonia di RSUD Wangaya untuk kasus, dan anak berusia 1259 bulan tidak dengan pneumonia di RSUD Wangaya untuk kontrol. Karakteristik subjek berupa jenis kelamin, usia, berat badan lahir, status ASI eksklusif, status imunisasi, riwayat asma, paparan asap, dan status gizi. Dilakukan matching pada variabel ASI eksklusif. Dan akan dilakukan analisis bivariat dengan uji McNemar dan multivariat dengan regresi logistik.

Hasil: Sebanyak total 96 subjek, dengan 48 subjek untuk masingmasing kelompok penelitian. Didapatkan hasil yang signifikan pada faktor resiko status imunisasi (nilai p 0.009 dan OR 5.209) dan faktor resiko paparan asap (nilai p 0.008 dan OR 2.238). Sedangkan jenis kelamin, status gizi, dan riwayat asma tidak didapatkan hasil yang signifikan sebagai fakto resiko pneumonia di RSUD Wangaya.

Simpulan: Status imunisasi yang tidak lengkap dan terpapar asap rokok merupakan faktor resiko terjadinya pneumonia pada anak usia 12-59 bulan di RSUD Wangaya.

Kata kunci: Pneumonia, balita, faktor resiko

Cite Pasal Ini: Budihardjo, S.N., Suryawan, I.W.B. 2020. Faktor-faktor resiko kejadian pneumonia pada pasien pneumonia usia 12-59 bulan di RSUD Wangaya. Intisari Sains Medis 11(1): 398-404. D0I: 10.15562/ism.v1111.645

\section{PENDAHULUAN}

Pneumonia adalah infeksi akut yang menyerang jaringan paru-paru (alveoli) yang disebabkan oleh bakteri, virus, maupun jamur. Terjadinya pneumonia pada anak balita seringkali bersamaan dengan terjadinya proses infeksi akut pada bronkus yang disebut bronchopneumonia. Gejala penyakit 
pneumonia ini berupa pernafasan yang cepat dan sesak pada balita yang dikarenakan serangan peradangan paru ini terjadi secara mendadak. ${ }^{1}$ Insiden pneumonia pada negara berkembang termasuk Indonesia hampir 30\% pada anak-anak di bawah umur lima tahun yaitu kurang lebih 10-20 kasus per 100 anak per tahunnya, dengan tingkat kematian yang tinggi. Pneumonia menyebabkan lebih dari 5 juta kematian per tahun pada anak balita di negara berkembang. ${ }^{2}$

Pneumonia adalah pembunuh utama balita di dunia, lebih banyak dibandingkan dengan gabungan penyakit AIDS, malaria dan campak. Persentasenya yaitu 19\% dari semua penyebab kematian balita, kemudian disusul diare 17\%, sehingga World Health Oganization (WHO) menjulukinya sebagai "the leading killer of children worldwide". Diantara lima kematian balita, satu disebabkan oleh pneumonia, namun tidak banyak perhatian terhadap penyakit ini sehingga pneumonia disebut juga pembunuh balita yang terlupakan atau the forgotten killer of children. ${ }^{3}$ Pada tahun 2015, pneumonia menyebabkan kematian pada lebih dari 2500 balita per hari atau dapat diperkirakan terdapat 2 balita meninggal setiap menit. WHO melaporkan bahwa 16\% dari seluruh kematian anak di bawah lima tahun disebabkan oleh pneumonia pada tahun 2015. Pada tahun yang sama, UNICEF melaporkan kurang lebih 14\% dari 147.000 balita di Indonesia meninggal karena pneumonia. ${ }^{4,5} \mathrm{Di}$ Indonesia, Pneumonia menduduki peringkat kedua penyebab kematian bayi $(12,3 \%)$ dan balita $(13,2 \%)$ setelah diare. ${ }^{1}$ Pneumonia termasuk dalam sepuluh penyakit terbanyak penyakit rawat inap di rumah sakit tahun $2010 .{ }^{6}$ Berdasarkan data Laporan Rutin Subdit ISPA Tahun 2017, didapatkan insiden (per 1000 balita) di Indonesia sebesar 20,54. Data dari Riskesdas juga menyatakan bahwa prevalensi pneumonia di Indonesia mengalami peningkatan dari tahun 2017 ke tahun 2018 yaitu dari 3.55\% di tahun 2017 menjadi 4\% di tahun 2018. Di Bali sendiri, prevalensi pneumonia juga mengalami peningkatan yaitu $2.05 \%$ pada 2017 menjadi sekitar 3.25\% pada tahun 2018. ${ }^{78}$

Salah satu upaya yang dilakukan untuk mengendalikan penyakit ini yaitu dengan meningkatkan cakupan penemuan pneumonia pada balita. Menurut Riskesdas 2017, target cakupan penemuan pneumonia adalah 80\%. Di Indonesia sendiri cakupan penemuan pneumonia sebesar 51.19\% yang berarti masih di bawah target cakupan. Sedangkan di Bali, angka cakupan penemuan pneumonia sebesar $64.25 \%$ dan masih kurang dari target cakupan. ${ }^{7}$ Pada penelitian yang dilakukan oleh Rasyid Z ditemukan bahwa BBLR, status imunisasi, pemberian ASI eksklusif, status gizi, jenis kelamin, pendidikan dan pekerjaan ibu menjadi faktor-faktor resiko yang menyebabkan terjadinya pneumoni pada balita. Menurut Mardani RA dkk pada tahun 2018, ada dua faktor yang berhubungan dengan kejadian pneumonia yatu faktor instrinsik dan faktor ekstrinsik. Faktor instrinsik merupakan faktor yang ada pada balita, meliputi umur balita, jenis kelamin, berat badan lahir rendah, status imunisasi, pemberian ASI, pemberian vitamin A, dan status gizi. Sedangkan faktor ekstrinsik merupakan faktor yang tidak ada pada balita meliputi kepadatan tempat tinggal, tipe rumah, ventilasi, jenis lantai, pencahayaan, kepadatan hunian, kelembaban, jenis bahan bakar, penghasilan keluarga, serta faktor ibu baik pendidikan, umur ibu juga pegetahuan ibu dan keberadaan keluarga yang merokok. ${ }^{9,10}$

Berdasarkan data prevalensi di atas serta penyebab pneumonia yang terdiri dari berbagai macam faktor, penulis tertarik untuk mengetahui tentang faktor-faktor yang berhubungan dengan kejadian pneumonia pada balita di RSUD Wangaya Kota Denpasar. Pada penelitian ini akan membahas mengenai beberapa faktor resiko yang berkaitan dengan terjadinya pneumonia yaitu umur balita, jenis kelamin, berat badan lahir, status imunisasi, pemberian ASI, status gizi, riwayat asma, dan paparan asap.

\section{METODE}

Jenis penelitian yang digunakan adalah observasional analitik dengan rancangan penelitian kasus dan kontrol dengan perbandingan 1:1. Penelitian ini dimulai dengan mengidentifikasi faktor resiko yang terjadi pada kelompok kasus dan kelompok kontrol. Antara kedua kelompok akan dilakukan matching pada variabel ASI eksklusif. Penelitian ini dilakukan untuk mengidentifikasi faktor-faktor resiko kejadian pneumonia pada pasien pneumonia usia 12-59 bulan di RSUD Wangaya. Penelitian ini dilakukan di Ruang Kaswari (bangsal anak) RSUD Wangaya sejak Januari 2019-Mei 2019.

Besar sampel minimal pada penelitian ini adalah 48 sampel untuk kelompok kasus dan 48 sampel untuk kelompok kontrol, sehingga total sampel adalah 96 anak dipilih dengan menggunakan consecutive sampling dan memenuhi kriteria inklusi dan eksklusi. Kriteria inklusi pada kelompok kasus adalah anak usia 12-59 bulan yang dirawat dengan diagnosa pneumonia di RSUD Wangaya Kota Denpasar, sedangkan kriteria inklusi pada kelompok kontrol adalah anak usia 12-59 bulan yang dirawat dengan diagnosa penyakit lain selain pneumonia di RSUD Wangaya Kota Denpasar. Sedangkan kriteria eksklusi pada penelitian ini meliputi anak dengan penyakit bawaan, mengalami sindroma tertentu, kelainan kongenital, immunocompromised, penyakit kronis; anak dengan penyakit infeksi lainnya; anak 
yang meninggal dunia saat dirawat; data rekam medis yang tidak lengkap.

Data demografik yang akan dicatat dari subjek berupa jenis kelamin, usia, berat badan lahir, status ASI eksklusif, status imunisasi, riwayat asma, paparan asap, dan status gizi. Sumber data dalam penelitian ini adalah berupa data sekunder yang berasal dari rekam medis pasien. Persetujuan penelitian dan penggunaan rekam medis telah disetujui oleh kepala bagian SMF Anak di RSUD Wangaya Denpasar.

Data yang ada kemudian diolah dan dilakukan analisa dengan Statistical Product and Service Solution (SPSS) 24 for Macbook. Analisis univariat bertujuan untuk mendeskripsikan karakteristik responden dalam penelitian. Analisis bivariat dilakukan dengan melakukan tabulasi silang untuk mencari hubungan antara masing-masing variabel bebas dan variabel tergantung dengan menggunakan uji McNemar. Hasil dari analisis bivariat digunakan untuk menyeleksi variabel yang akan dimasukkan ke dalam analisis multivariat yaitu variabel yang pada analisis bivariat memiliki nilai $\mathrm{p}<0,25$. Pada analisis multivariat, variabel-variabel bebas dianalisis terhadap variabel tergantung dengan menggunakan uji regresi logistik.

\section{HASIL}

Selama bulan Januari 2019 sampai Mei 2019, ditemukan 48 subjek untuk kelompok balita dengan pneumonia dan 48 subjek untuk kelompok balita bukan pneumonia. Dilakukan matching berupa ASI eksklusif (Tabel 1). Karakteristik sampel penelitian tertera pada Tabel 2.

Pada tabel 1 dapat dilihat bahwa dilakukan matching pada variabel ASI eksklusif. Balita yang mendapatkan ASI eksklusif pada kelompok kasus maupun kontrol adalah sebanyak 27 (56.3\%) sampel, sedangkan yang tidak mendapatkan ASI eksklusif adalah sebanyak 21 (43.8\%) sampel.

Berdasarkan tabel 2 dapat diketahui bahwa sampel berjenis kelamin laki-laki di kasus sebanyak $27(56.3 \%)$ sampel dan di kontrol sebanyak 28 (58.3\%) sampel. Sedangkan yang berjenis kelamin perempuan sebanyak 21 (43.8\%) sampel pada kasus dan 20 (41.7\%) sampel pada kontrol. Rata-rata usia balita dengan pneumonia adalah 26.10 bulan, sedangkan rata-rata usia pada balita bukan dengan pneumonia adalah sebesar 30.37 bulan. Berat badan lahir balita dengan pneumonia mempunyai rata-rata 2915.63 gram, sedangkan pada balita yang bukan dengan pneumonia, rata-rata berat badan lahirnya adalah 3062.50 gram. Balita dengan status imunisasi lengkap ditemukan lebih banyak darpada yang tidak mendapatkan imunisasi lengkap baik di kasus maupun di kontrol. Di kasus, balita dengan imunisasi lengkap sebanyak $30(62.5 \%)$ sampel sedangkan balita dengan imunisasi tidak lengkap sebanyak 18 (37.5\%) sampel. Sedangkan pada kontrol, balita dengan

Tabel 1 Komparibilitas berdasarkan status ASI eksklusif pada kasus dan kontrol

\begin{tabular}{lccc}
\hline Status ASI Eksklusif & $\begin{array}{c}\text { Pneumonia } \\
\mathbf{n}(\%)\end{array}$ & $\begin{array}{c}\text { Tidak pneumonia } \\
\mathbf{n}(\%)\end{array}$ & Nilai p \\
\hline ASI Eksklusif & $27(56.3 \%)$ & $27(56.3 \%)$ & 1.000 \\
Tidak ASI Eksklusif & $21(43.8 \%)$ & $21(43.8 \%)$ & \\
\hline
\end{tabular}

Tabel 2 Karakteristik subjek penelitian

\begin{tabular}{llcc}
\hline Variabel & Pneumonia & (n=42) & $\begin{array}{c}\text { Bukan pneumonia } \\
(\mathbf{n}=\mathbf{4 2})\end{array}$ \\
\hline Jenis kelamin & Laki-laki & $27(56.3 \%)$ & $28(58.3 \%)$ \\
& Perempuan & $21(43.8 \%)$ & $20(41.7 \%)$ \\
Usia & Mean & 26.38 bulan & 29.78 bulan \\
Berat Badan Lahir & Mean & 2913.10 gram & 3061.90 gram \\
Status Imunisasi & Lengkap & $30(62.5 \%)$ & $43(89.6 \%)$ \\
& Tidak lengkap & $18(37.5 \%)$ & $5(10.4 \%)$ \\
Status Gizi & Kurang & $16(33.3 \%)$ & $6(12.5 \%)$ \\
Riwayat Asma & Tidak kurang & $32(66.7 \%)$ & $42(87.5 \%)$ \\
Paparan asap & Ada & $20(41.7 \%)$ & $5(10.4 \%)$ \\
& Tidak ada & $28(58.3 \%)$ & $43(89.6 \%)$ \\
& Terpapar & $35(72.9 \%)$ & $20(41.7 \%)$ \\
& Tidak terpapar & $13(27.1 \%)$ & $28(58.3 \%)$ \\
\hline
\end{tabular}


Tabel 3 Analisis bivariat jenis kelamin

\begin{tabular}{llcccc}
\hline & & \multicolumn{2}{c}{ Kontrol } & & \\
\cline { 3 - 4 } Variabel & & Laki-laki & Perempuan & Total & Nilai p \\
\hline \multirow{2}{*}{ Kasus } & Laki-laki & $16(33.3 \%)$ & $11(22.9 \%)$ & $27(56.3 \%)$ & 1.000 \\
& Perempuan & $12(25.0 \%)$ & $9(18.8 \%)$ & $21(43.8 \%)$ & \\
\multirow{2}{*}{ Total } & & $28(58.3 \%)$ & $20(41.7 \%)$ & $48(100 \%)$ \\
\hline
\end{tabular}

Berdasarkan hasil uji McNemar didapatkan nilai $\mathrm{p}=1.000$ dengan nilai $\mathrm{OR}(\mathrm{B} / \mathrm{C})=0.91$.

Tabel 4 Analisis bivariat status imunisasi

\begin{tabular}{llcllc}
\hline \multirow{2}{*}{ Variabel } & & \multicolumn{2}{c}{ Kontrol } & \multirow{2}{*}{ Total } & Nilai p \\
\cline { 3 - 4 } Kasus & Tidak Lengkap & $2(4.2 \%)$ & $16(33.3 \%)$ & $18(37.5 \%)$ & 0.004 \\
& Lengkap & $3(6.3 \%)$ & $27(56.3 \%)$ & $30(62.5 \%)$ & \\
\multirow{2}{*}{ Total } & & $5(10.4 \%)$ & $43(89.6 \%)$ & $48(100 \%)$ \\
\hline
\end{tabular}

Berdasarkan hasil uji McNemar didapatkan nilai $\mathrm{p}=0.004$ dengan nilai $\mathrm{OR}(\mathrm{B} / \mathrm{C})=5.33$.

Tabel 5 Analisis status gizi

\begin{tabular}{|c|c|c|c|c|c|}
\hline \multirow{2}{*}{ Variabe } & & \multicolumn{2}{|c|}{ Kontrol } & \multirow[b]{2}{*}{ Total } & \multirow[b]{2}{*}{ Nilai $p$} \\
\hline & & Kurang & Tidak kurang & & \\
\hline \multirow[t]{2}{*}{ Kasus } & Kurang & $4(8.3 \%)$ & $12(25 \%)$ & $16(33.3 \%)$ & 0.013 \\
\hline & Tidak kurang & $2(4.2 \%)$ & $30(62.5 \%)$ & $32(66.7 \%)$ & \\
\hline Total & & $6(12.5 \%)$ & $42(87.5 \%)$ & $48(100 \%)$ & \\
\hline
\end{tabular}

Berdasarkan hasil uji McNemar didapatkan nilai $\mathrm{p}=0.013$ dengan nilai $\mathrm{OR}(\mathrm{B} / \mathrm{C})=6$.

Tabel 6 Analisis riwayat asma

\begin{tabular}{llcccc}
\hline & & \multicolumn{3}{c}{ Kontrol } & \\
\cline { 3 - 4 } Variabel & & Ada & Tidak Ada & Total & Nilai p \\
\hline \multirow{2}{*}{ Kasus } & Ada & $1(2.1 \%)$ & $19(39.6 \%)$ & $20(41.7 \%)$ & 0.003 \\
& Tidak ada & $4(8.3 \%)$ & $24(50 \%)$ & $28(58.3 \%)$ & \\
\multirow{2}{*}{ Total } & & $5(10.4 \%)$ & $43(89.6 \%)$ & $48(100 \%)$ \\
\hline
\end{tabular}

Berdasarkan hasil uji McNemar didapatkan nilai $\mathrm{p}=0.003$ dengan nilai $\mathrm{OR}(\mathrm{B} / \mathrm{C})=4.75$

Tabel 7 Analisis paparan asap

\begin{tabular}{llcccc}
\hline \multirow{2}{*}{ Variabel } & & \multicolumn{2}{c}{ Kontrol } & \\
\cline { 3 - 4 } Kasus & Terpapar & Terpapar & Tidak terpapar & Total & Nilai p \\
\cline { 3 - 4 } & Tidak terpapar & $14(29.2 \%)$ & $21(43.8 \%)$ & $35(72.9 \%)$ & 0.006 \\
\multirow{2}{*}{ Total } & $6(12.5 \%)$ & $7(14.6 \%)$ & $13(27.1 \%)$ & \\
\hline
\end{tabular}

Berdasarkan hasil uji McNemar didapatkan nilai $\mathrm{p}=0.006$ dengan nilai $\mathrm{OR}(\mathrm{B} / \mathrm{C})=3.5$.

Tabel 8 Rangkuman hasil analisis bivariat

\begin{tabular}{lccc}
\hline Faktor risiko & Jenis analisis & Nilai p & OR \\
\hline Jenis kelamin & McNemar & 1.000 & 0.91 \\
Status imunisasi & McNemar & 0.004 & 5.33 \\
Status gizi & McNemar & 0.013 & 6 \\
Riwayat asma & McNemar & 0.003 & 4.75 \\
Paparan asap & McNemar & 0.006 & 3.5 \\
\hline
\end{tabular}


Tabel 9 Hasil analisis multivariat

\begin{tabular}{lccc}
\hline Variabel & Exp (B) & IK95\% & P value \\
\hline Status imunisasi & 5.209 & $1.499-18.100$ & 0,009 \\
Status gizi & 0.383 & $0.097-1.509$ & 0,170 \\
Riwayat asma & 0.378 & $0.113-1.263$ & 0,114 \\
Paparan asap & 2.238 & $2.082-2.690$ & 0.008 \\
\hline
\end{tabular}

Tabel 10 Faktor-faktor yang berhubungan dengan kejadian pneumonia

\begin{tabular}{lccc}
\hline Variabel & OR & IK 95\% & Nilai p \\
\hline Status imunisasi & 5.209 & $1.499-18.100$ & 0,009 \\
Paparan asap & 2.238 & $2.082-2.690$ & 0.008 \\
\hline
\end{tabular}

status imunisasi lengkap sebanyak 43 (89.6\%) sampel dan yang imunisasi tidak lengkap sebanyak $5(10.4 \%)$ sampel. Status gizi kurang pada kasus dan kontrol, berturut-turut sebanyak 16 (33.3\%) sampel dan $6(12.5 \%)$ sampel. Sedangkan status gizi yang tidak kurang pada kasus dan kontrol, berturut-turut sebanyak 32 (66.7\%) sampel dan $42(87.5 \%)$ sampel. Balita dengan riwayat asma pada kasus sebanyak 20 (41.7\%) sampel, sedangkan pada kelompok kontrol sebanyak 5 (10.4\%) sampel. Balita yang mendapat paparan asap pada kelompok kasus sebanyak 35 (72.9\%) sampel sedangkan pada kelompok kontrol sebanyak 20 (41.7\%) sampel.

Analisis bivariat untuk data kategorikal berpasangan menggunakan uji McNemar. Nilai $\mathrm{p}<0.25$ akan dilanjutkan dengan analisis multivariat. Nilai Odds Ratio (OR) dihitung menggunakan rumus OR dengan matching, yaitu: $\mathrm{OR}=\mathrm{B} / \mathrm{C}$.

Pada analisis secara bivariat didapatkan faktor risiko yang akan dilakukan analisis multivariat $(\mathrm{p}<0.25)$ yaitu status imunisasi, status gizi, riwayat asma, dan paparan asap.

Berdasarkan tabel 9, diketahui dari hasil uji regresi logistik, faktor risiko status imunisasi nilai $\mathrm{p}=0,009 \quad(\mathrm{p} \leq 0,05)$ dengan OR sebesar 5.209 (IK 95\% 1.499-18.100) yang menunjukkan bahwa status imunisasi merupakan faktor risiko kejadian pneumonia di Ruang Kaswari RSUD Wangaya Kota Denpasar. Faktor risiko status gizi nilai $\mathrm{p}=0,170$ ( $>00,05)$ dengan OR sebesar 0.383 (IK 95\% 0.0971.509) yang menunjukkan bahwa status gizi bukan merupakan faktor risiko kejadian pneumonia di Ruang Kaswari RSUD Wangaya Kota Denpasar. Sedangkan faktor risiko riwayat asma nilai $\mathrm{p}=0,114$ ( $p>0,05$ ) dengan OR sebesar 0.378 (IK 95\% 0.1131.263) yang menunjukkan bahwa riwayat asma bukan merupakan faktor risiko kejadian pneumonia di Ruang Kaswari RSUD Wangaya Kota Denpasar. Faktor risiko paparan asap nilai $\mathrm{p}=0,008$ $(\mathrm{p} \leq 0,05)$ dengan OR sebesar 2.238 (IK 95\% 2.0822.690) yang menunjukkan bahwa paparan asap merupakan faktor risiko kejadian pneumonia di Ruang Kaswari RSUD Wangaya Kota Denpasar.

\section{DISKUSI}

Penelitian mengenai faktor-faktor yang mempengaruhi kejadian pneumonia memberikan hasil yang berbeda-beda dan telah diketahui bahwa pneumonia disebabkan oleh berbagai faktor. Pada penelitian ini dilakukan analisis bivariat dan multivariat. Pada analisis bivariat didapatkan hasil yang bermakna sebagai faktor risiko terjadinya pneumonia pada anak usia 12 - 59 bulan di RSUD Wangaya Kota Denpasar berupa jenis kelamin, status imunisasi, status gizi, riwayat asma, dan paparan asap. Pada saat dilanjutkan dengan analisis multivariat, didapatkan hasil yang bermakna secara signifikan sebagai faktor risiko terjadinya pneumonia pada anak usia 12-59 bulan di RSUD Wangaya berupa status imunisasi lengkap dan paparan asap rokok yang didapatkan dari anggota keluarga yang merokok.

Penelitian ini menggunakan variabel ASI eksklusif untuk dijadikan variabel matching. Nutrisi yang terkandung didalam ASI menjamin status gizi bayi sehingga angka kesakitan dan kematian anak menurun. Beberapa penelitian epidemiologis menyatakan bahwa ASI melindungi bayi dan anak dari penyakit infeksi salah satunya yaitu pneumonia. Penelitian yang dilakukan oleh Sugihartono \& Nurjazuli tahun 2012 menyatakan bahwa faktor paling dominan terhadap kejadian pneumonia pada anak balita adalah riwayat pemberian ASI eksklusif dengan nilai $\mathrm{OR}=8,105$. Sehingga balita yang tidak mendapatkan ASI eksklusif berisiko 8,105 kali mengalami pneumonia. ${ }^{11}$ Selanjutnya penelitian yang dilakukan Hartati S et al tahun 2011 menyimpulkan bahwa balita yang tidak mendapatkan ASI eksklusif berisiko 4,47 kali mengalami pneumonia dibanding balita yang mendapatkan ASI eksklusif. ASI eksklusif mengurangi tingkat kematian bayi yang disebabkan berbagai penyakit yang umum menimpa anak-anak seperti diare dan radang paru karena mengandung protein, laktoferin, imunoglobin, antibody terhadap bakteri, virus, jamur, dll. ${ }^{12}$

Pada penelitian ini didapatkan bahwa status imunisasi memiliki hasil yang signifikan dalam menyebabkan pneumonia dengan nilai p 0.009 dan OR 5.209, yang berarti bahwa balita dengan status imunisasi tidak lengkap mempunyai resiko 5,209 kali lebih besar untuk terkena pneumonia daripada balita dengan status imunisasi lengkap sesuai usianya. Hasil serupa didapatkan pada penelitian Hartati S et al pada tahun 2011 yang mendapatkan bahwa status imunisasi merupakan salah satu faktor yang mempengaruhi terjadinya pneumonia pada balita yaitu dengan nilai p 0.002 dan OR $3.21 .{ }^{12}$ 
Hasil serupa lainnya dapat ditemukan di penelitian yang dilakukan oleh Rasyid Z, Tambunan $\mathrm{S}$ et al pada 2013 dan Iswari BM et al pada 2016., ${ }^{9,13,14}$ Hasil yang tidak serupa dapat ditemukan pada penelitian yang dilakukan oleh Efni $Y$ et al pada tahun 2014. ${ }^{30}$ Pneumonia termasuk ke dalam penyakit yang dapat dicegah dengan imunisasi (PD3I). Imunisasi merupakan cara untuk meningkatkan kekebalan seseorang terhadap suatu penyakit, sehingga apabila kelak terpajan pada penyakit tersebut ia tidak menjadi sakit. ${ }^{14}$ Menurut World Health Organization dalam Global Immunization Data tahun 2010, menyebutkan bahwa 1,5 juta anak meninggal karena penyakit yang dapat dicegah dengan imunisasi dan hampir $17 \%$ kematian pada anak dibawah usia 5 tahun dapat dicegah dengan imunisasi. ${ }^{14}$

Paparan asap terutama asap rokok dari orang sekitar didapatkan bermakna secara statistik pada penelitian ini dengan nilai p sebesar 0,008 dan OR 2.238, yang berarti bahwa balita yang terkena paparan asap rokok mempunyai resiko 2,238 kali lebih besar untuk terkena pneumonia daripada balita yang tidak terkena paparan asap rokok. Hal serupa didapatkan pada penelitian yang dilakukan oleh Hartati S et al di Jakarta tahun 2011 yang mengatakan bahwa paparan asap rokok merupakan salah satu faktor yang mempengaruhi kejadian pneumonia, dengan nilai p 0.013 dan OR 2.53. ${ }^{12}$ Namun hal yang tidak serupa dapat ditemukan pada penelitian Efni $\mathrm{Y}$ et al dan penelitian Mokoginta $\mathrm{Y}$ et al yang mengatakan bahwa paparan asap rokok tidak mempunyai hubungan bermakna dengan kejadian pneumonia. ${ }^{15,16}$ Sumber asap rokok di dalam ruangan (indoor) lebih membahayakan daripada di luar ruangan (outdoor), karena sebagian besar balita menghabiskan $60-90 \%$ waktunya di dalam ruangan. ${ }^{1}$ Asap rokok yang dihisap baik pada perokok aktif maupun pasif akan menyebabkan fungsi silia menurun bahkan tidak berfungsi. Jika silia tidak berfungsi, maka tubuh akan memproduksi dahak yang berlebihan. Selain itu, potensi infeksi pada saluran napas sangat besar. Asap rokok juga dapat menyebabkan iritasi, peradangan dan penyempitan saluran napas. Proses penyembuhan bagi penderita pneumonia akan membutuhkan waktu yang lama jika penderita masih terpapar asap rokok karena proses pertahanan tubuh terhadap infeksi tetap akan terganggu. ${ }^{17}$

Pada penelitian ini tidak didapatkan hubungan yang bermakna antara jenis kelamin, status gizi, dan riwayat asma sebagai faktor risiko terjadinya pneumonia.

\section{KETERBATASAN}

Kelemahan pada penelitian ini antara lain, data dalam penelitian ini masih menggunakan data sekunder, waktu dalam pengumpulan sampel yang cukup singkat, dan juga masih banyak faktor resiko yang belum diteliti serta subyek dalam penelitian yang kurang variatif karena hanya mengambil dari satu rumah sakit sehingga tidak bisa digeneralisasikan. Oleh karena itu, perlu dilakukan penelitian lebih lanjut mengenai faktor resiko yang dapat menyebabkan kejadian pneumonia dengan cakupan populasi terjangkau yang lebih luas serta waktu yang lebih panjang.

\section{SIMPULAN}

Status imunisasi yang tidak lengkap dan paparan asap merupakan faktor resiko terjadinya pneumonia pada anak usia 12-59 bulan di RSUD Wangaya Kota Denpasar. Didapatkan resiko 5,209 kali lebih besar terinfeksi pneumonia pada balita yang tidak mendapatkan imunisasi lengkap. Didapatkan resiko 2,238 kali lebih besar terinfeksi pneumonia pada balita yang terpapar asap rokok orang sekitarnya.

\section{UCAPAN TERIMA KASIH}

Ucapan terima kasih penulis berikan kepada pasien di ruang kaswari (bangsal anak) RSUD Wangaya dan Bagian/SMF Ilmu Kesehatan Anak RSUD Wangaya atas kesempatan dan bimbingan yang telah diberikan dalam penulisan penelitian ini.

\section{KONFLIK KEPENTINGAN}

Penulis menyatakan tidak terdapat konflik kepentingan (conflict of interest) pada penulisan laporan penelitian ini.

\section{PENDANAAN}

Penulis bertanggung jawab terhadap seluruh pembiayaan dalam pembuatan laporan penelitian ini.

\section{KONTRIBUSI PENULIS}

Penulis bertanggung jawab dalam pembuatan dan penulisan laporan penelitian ini.

\section{DAFTAR PUSTAKA}

1. Kementrian Kesehatan Republik Indonesia. Pneumonia Balita. Buletin Jendela Epidemiologi, Volume 3. Jakarta: Kementrian Kesehatan RI; 2010.

2. Latief A. Pelayanan Kesehatan Anak di Rumah Sakit Standar WHO. Jakarta: Depkes; 2009.

3. Nurnajiah M, Rusdi, Desmawati. Hubungan Status Gizi dengan Derajat Pneumonia pada Balita di RS. Dr. M. Djamil Padang. Jurnal Kesehatan Andalas. 2016; 5(1):250-5. 
4. IDAI 2015. Pola Pengasuhan Anak Menekan Kejadian Pneumonia. http://www.idai.or.id/artikel/klinik/pengasuhananak/menekan-pneumonia - diaksespada September 2019.

5. WHO 2019. Pneumonia. https://www.who.int/news-room/ fact-sheets/detail/pneumonia - diaksespada September 2019.

6. Kementrian Kesehatan RI. Profil Data Kesehatan Indonesia Tahun 2011. Jakarta : Kementrian Kesehatan RI; 2012.

7. Kementrian Kesehatan RI. Data dan Informasi Profil Kesehatan Indonesia 2016. Jakarta : Pusat Data dan Informasi Kementrian Kesehatan RI; 2017.

8. Kemetrian Kesehatan RI. Data dan Informasi Profil Kesehatan Indonesia 2017. Jakarta: Kementrian Kesehatan RI; 2018.

9. Rasyid Z. Faktor-Faktor yang Berhubungan dengan Kejadian Pneumonia Anak Balita di RSUD Bangkinang Kabupaten Kampar. Jurnal Kesehatan Komunitas. November 2013; 2(3):136-140.

10. Mardani RA, Pradigdo SF, Mawarni A. Faktor Resiko Kejadian Pneumonia pada Anak Usia 12-48 Bulan (Studi di Wilayah Kerja Puskesmas Gombong II Kabupaten Kebumen Tahun 2017). Jurnal Kesehatan Masyarakat. Januari 2018; 6(1):581-590.

11. Sugihartono, Nurjazuli. Analisis faktor risiko kejadian Pneumonia pada balita di wilayah kerja Puskesmas Sideorja Kota Pagar Alam. Jurnal Kesehatan Lingkungan Indonesia. 2012; 11(1):82-86.

12. Hartati, S, Nurhaeni N, Gayatri D. Faktor Resiko Terjadinya Pneumonia pada Anak Balita. Jurnal Keperawatan Indonesia. Maret 2012; 15(1): 13-20.
13. Tambunan S, Suharyo, Saptorini KK. Artikel Ilmiah: Faktor-Faktor Risiko Kejadian Pneumonia pada Balita di Wilayah Kerja Puskesmas Kedungmundu Kota Semarang Tahun 2013. Semarang: Fakultas Kesehatan Universitas Dian Nuswantoro; 2013.

14. Iswari BM, Nurhidayah I, Hendrawati S. Hubungan Status Imunisasi: DPT-HB-HiB dengan Pneumonia pada Balita Usia 12-24 Bulan di Puskesmas Babakam Sari Kota Bandung. E-journal UMM. Juli 2017; 8(2): 101-115.

15. Efni Y, Machmud R, Pertiwi D. Faktor Resiko yang Berhubungan dengan Kejadian Pneumonia pada Balita di Kelurahan Air Tawar Barat Padang. Jurnal Kesehatan Andalas. 2016; 5(2): 365-370.

16. Mokoginta D, Arsin A, Sidik D. Skripsi: Faktor Resiko Kejadian Pneumonia pada Anak Balita di Wilayah Kerja Puskesmas Sudiang Kota Makassar. Makassar: Fakultas Kesehatan Masyarakat Universitas Hasanuddin; 2013.

17. Kusumawati I. Hubungan Antara Status Merokok Anggota Keluarga dengan Lama Pengobatan ISPA Balita di Kecamatan Jenawi. Thesis. Surakarta: Universitas Sebelas Maret; 2010.

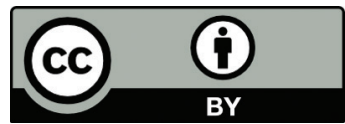

This work is licensed under a Creative Commons Attribution 